$\left.\begin{array}{c}\text { Journal of Innovative Engineering } \\ \text { and Natural Science }\end{array}\right)$

\title{
Geçirgen ve viskoz sınırlar kullanılarak idealleştirilen sonsuz zemin ortamının beton ağırlık barajların dinamik davranışına etkisi
}

Hasan Seslia,

a'Inşaat Mühendisliği Bölümü, Mühendislik Fakültesi, Yalova Üniversitesi, Yalova, 77200, Türkiye.

MAKELE BİLGİSI

Makale Geçmişi:

Geliş 17 Aralık 2021

Düzeltme 09 Ocak 2022

Kabul 20 Ocak 2022

Çevrimiçi mevcut

Anahtar Kelimeler:

Geçirgen sınırlar

Viskoz sınırlar

Yapı-zemin etkileşimi

Beton ağırlık barajlar

\section{ÖZET}

\begin{abstract}
Yapı ve yapının üzerinde inşa edildiği zeminin karşılıklı etkileşimi yapısal davranış üzerinde oldukça etkili olmaktadır. Baraj gibi sosyoekonomik açıdan önemli yapıların dinamik davranışlarının zemin özelliklerinden bağımsız olarak ele alınması kabul edilemez. Fakat, sonsuz zemin ortamının kompleks davranışının baraj gövdesinin yapısal davranışı gibi idealleştirilmesi pek kolay değildir. Bu nedenle sonsuz zemin ortamının malzeme davranışının yanında, sonsuzluk özelliklerinin de yapısal modellemelerde yansıtılabilmesi gerekmektedir. Yapı ve zemin etkileşimin beraber olarak dikkate alındığı sonlu eleman çözüm yöntemlerinde sonsuz zemin ortamının boyutu suni etkilerin ortaya çıkmasına sebep olmaktadır. Sınırlı zemin ortamında ortaya çıkan suni etkilerin yapısal davranışı etkilememesi için zemin ortamı için uygun boyut ve sınır şartının seçilmesi gerekmektedir. Bu çalışmada yapı-zemin etkileşim çalışmaları için önerilen viskoz ve geçirgen sınırların etkisi araştırılmaktadır. Sayısal uygulama için Sarıyar beton ağırlık barajı dikkate alınmıştır. Yapılan çalışma sonucunda baraj-zemin etkileşim çalışmalarında kullanılan viskoz ve geçirgen sınırların çözüm maliyetini azalttığı ve dinamik analizlerde daha pratik çözüm sağladığı ortaya konmuştur.
\end{abstract}

2022 JIENS Tüm hakları saklıdır.

The effect of the infinite soil domain idealized by using transmitting and viscous boundaries on the dynamic behavior of concrete gravity dams

\section{ARTICLE INFO}

Article history:

Received 17 Dec 2021

Received in revised form 09 January 2022

Accepted 20 January 2022

Available online

\section{Keywords:}

Transmitting boundaries

Viscous boundaries

Soil-structure interaction

Concrete gravity dams

\begin{abstract}
The interaction between the structure and the soil on which the structure is built has a very effective effect on the structural behavior. It is unacceptable to consider the dynamic behavior of socioeconomically important structures such as dams independently of soil properties. However, the complex behavior of the infinite soil medium is not easy to idealize as the structural behavior of the dam. For this reason, in addition to the material properties of the infinite soil medium, the infinity feature should also be reflected in the structural modeling. In the finite element methods, where the interaction between the structure and the ground is taken into account, the size of the infinite soil medium causes artificial effects. Appropriate dimesions and boundary conditions should be selected for the soil domain so that artificial effects in the bounded soil domain do not affect the structural behavior. In this study, the effect of viscous and transmitting boundaries proposed for the soilstructure interaction studies was investigated. Saryyar concrete gravity dam was taken into account for the numerical application. As a result of the study, it has been revealed that the viscous and transmitting boundaries used in dam-soil interaction studies reduce the solution cost and provide a more practical solution in dynamic analysis.
\end{abstract}

2022 JIENS All rights reserved. 


\section{GİRİ̧̧}

Dünyanın oluşumu itibari ile belirli bölgelerde depremlerin sıkça oluştuğu ve bunun neticesinde insanlar ve yapılar oldukça etki altında kalmıştır. Depremin karakteristiği ve buna bağlı yapısal davranış hakkında bilinçlenme sonucu güvenli yapılar inşa edilerek olası can ve mal kayıpları önüne geçilebilir.

Beton ağırlık barajlar çok miktarda su depolayan önemli yapılardır. Bu sebeple, özellikle deprem esnasında yıkılmaları bulundukları çevrede telafisi imkânsız kayba yol açabilir. Büyüklükleri açısından değerlendirildiğinde bu tür yapıların dinamik davranışları inşa edildikleri zeminden bağımsız düşünülemez. Yapısal davranışlar, zemin özelliklerine bağlı olarak değiştiği gibi zeminin de davranışı yapısal özelliklere bağlı olarak değişmektedir [1]. Bu sebeple, beton ağırlık barajlar için zeminin yükleme öncesi ve sonrası davranışının çok iyi irdelenmesi gerekmektedir.

Zemin davranışının irdelenmesinden önce dinamik etkiye maruz yapının titreşimi sonucu oluşan ve dinamik etkiyle sonsuz zemin ortamında hareket eden dalga yayılımını gerçeğe yakın olarak yansıtan sınırsız zemin ortamının uygun yaklaşım ile ifade edilebilmesi gerekmektedir. Bu doğrultuda birçok araştırmacı tarafından yapızemin etkileşimi ve dalga yayılımı üzerinde çalışmalar yapılmıştır. Lysmer vd., sonsuz sistemin dinamik titreşimi sonucu ortam sınırlarına enerjinin sönümlenmesi için viskoz sınır şartını önermiş ve dinamik etki sonucu zemin ortamında oluşan P- ve S-dalgaları için bu sınır şartlarını idealleştirmişlerdir [2]. Lysmer 1970 yılında genelleştirilmiş Rayleigh dalgalarının çok tabakalı elastik zemin ortamındaki analizi için basit bir sayısal yöntem ortaya koymuştur [3]. Smith 1974 yılında verilerin süperpoze edilmesi nedeniyle tek bir çözümden oldukça maliyetli olan ancak dalga yansımalarını önemli ölçüde azaltan yansıtmayan sınırları geliştirmiştir [4]. Hwang vd., özel bir viskoz sınır yardımıyla zemin kütlesindeki enerji kaybının 3 boyutlu etkilerinin, 2 boyutlu düzlem şekil değiştirme analizleri ile bağlantılı yaklaşık bir yöntem içerisinde dikkate alınabileceğini göstermişlerdir. Bu yeni sınırın etkilerini, iki boyutlu düzlem şekil değiştirme, eksenel simetrik ve basitleştirilmiş üç boyutlu analiz yöntemleriyle birlikte çalışmışlardır. Eksenel simetrik yapılarda yapı merkezinden itibaren yapı çapına eşit mesafelerde yapının zemin davranışı üzerindeki etkisinin ihmal edilebileceğini ortaya koymuşlardır [5]. Bettess (1977), Lagrange polinomlarına benzer, viskoz akış olmak üzere sonsuza uzanan birçok probleme uygulanabilen sınırlı elemanlar yöntemini önermiştir [6]. Clayton ve Engquist (1977), akustik ve elastik dalga yayılımı ile sonsuz bir alandaki fiziksel davranışı temsil etmek için sınırlı alandaki yapay yansımaları en aza indirecek sayısal dalga benzeşimi için sınır şartlarını geliştirmişlerdir [7]. Dumanoğlu, geçirgen ve viskoz sınırlar ile beraber zemine gömülü yapıların dinamik analizinde rijit taban kabulünün yerini alacak yansıtmayan sınırları önermiştir [8]. Liao vd., ekstrapolasyon formülü şeklinde ifade edilebilen ve yapay bir sınırdan dalgaların geçişini sağlamasının yanında sonlu elemanlarda kullanılabilen sayısal bir yöntem önermişlerdir [9]. Berenger, elektromanyetik dalgaların yansımadan sönümlenmesi için özel olarak tasarlanmış bir emici tabakanın kullanımına dayanan PML tekniğini önermiştir [10]. Chuhan vd., yapı-zemin etkileşimi dinamik analizleri için sonlu elemanlar, sınır elemanlar, sonsuz elemanlar ve sonsuz sınır elemanlarından oluşan birleşik bir model sundular [11]. Wolf vd., sonlu eleman çözüm hassasiyetine yakın çözümlerin elde edilmesini sağlamak üzere sınır eleman metodu ile sonlu eleman metodunun birleşiminden oluşan tutarlı sonsuz küçük sonlu eleman hücre yöntemini ortaya koymuşlardır [12]. Park vd., zaman tanım alanında sismik yapı-zemin etkileşimi analizlerinde sonsuz ortamdaki dalga yayılımını modellemek için daha az hesap süresi ve hesap hacmi gerektiren Süreksiz Galerkin metodu esaslı bir yöntem geliştirmişlerdir [13]. Liu vd., yapı-zemin etkileşim sisteminin analizleri için sönümleyici ve yay elemanları 
kullanarak zaman tanım alanında mod süperpozisyon yöntemini esas alan basitleştirilmiş bir yöntem geliştirmişlerdir [14]. Du vd., yakın alan temel kayasındaki elastik ötesi davranışı ortaya koymak için kemer barajların sismik davranışının hesabı için kullanılan zaman tanım alanındaki hesap yöntemini geçirgen sınır ve sonlu eleman yöntemini birleştirerek geliştirmişlerdir [15]. Kucukcoban ve Kallivokas, 2 boyutlu elastik heterojen ortamların yerdeğiştirme-gerilme bölünmemiş alan formülasyonlarının sonlu eleman uygulamalarını önermişlerdir [16] ve ileride ki çalışmalarda heterojen ortamlarda dalga hareketinin sayısal simülasyonu için hibrit formülasyon geliştirmişlerdir [17]. Mazzotti vd. sınırsız izotropik viskoelastik ortama gömülü viskoelastik dalga kılavuzlarının dağılım özelliklerinin hesaplanması için 2.5D Sınır Eleman Yöntemi (BEM) ile birleştirilmiş bir Yarı-Analitik Sonlu Eleman (SAFE) formülasyonu önermişlerdir [18]. Mazzotti vd., viskoz olmayan akışkanlara daldırılmış genel kesitli elastik mekanik dalga kılavuzlarındaki dağılım parametrelerinin hesaplanması için sayısal bir yöntem geliştirmişlerdir. Bu yöntemde, katı dalga kılavuzunu tanımlamak için yarı analitik bir sonlu eleman formülasyonu ve çevreleyen sınırsız sıvıyı temsil etmek için yaklaşık 2 buçuk boyutlu bir sınır eleman yöntemi kullanılmıştır [19]. Poul ve Zerva, Yapı-zemin etkileşim analizleri için sınırsız temel alanını modellemede viskoelastik PML elemanlarının performansını değerlendirmiş ve elde edilen sonuçları viskoz tipi emici sınır şartlarına göre elde edilen sonuçlar ile karşılatırmışlardır [20]. Zhang vd. etki alanı azaltma yöntemi (DRM) ve mükemmel uyumlu tabakalar yöntemini (PML) ABAQUS [21] sonlu eleman paket programına uygulayarak 2 ve 3 boyutlu homojen ve heterojen zemin ortamında kayma dalgalarının yansımasını doğrulamışlardır [22].

$\mathrm{Bu}$ çalışmada zemin içerisindeki dalga yayılımının 3 boyutlu etkilerini dikkate alan viskoz sınırlar ve Rayleigh dalgalarını absorbe eden geçirgen sınırlar kullanılarak oluşturulan sayısal model yardımıyla beton ağırlık barajların dinamik davranışı incelenmiştir. Sayısal uygulama olarak Sarıyar beton ağırlık barajı seçilmiştir. Yapı-zemin etkileşim problemlerinin yaklaşık 3-boyutlu analiz programı (FLUSH) [23] ve sonlu eleman paket programı ANSYS [24] kullanılarak Sarıyar beton ağırlık barajına ait yapı-zemin etkileşim sisteminin dinamik analizi gerçekleştirilmiştir. Zeminin sınırlarında; rijit sınır, viskoz sınır ve geçirgen sınır koşulları dikkate alınarak yapısal davranış değerlendirmesi yapılmıştır.

\section{TEORİK METOD}

Yapı-zemin etkileşiminin yapısal davranışa olan etkisinin ortaya konabilmesi için yukarıda da bahsedildiği gibi genellikle 3 farklı yönteme başvurulmaktadır (ayrık sistem, yay-sönümleyici ile idealleştirilmiş sistem ve yapızemin sonlu eleman modeli). Bu çalışmada yapı ve zeminin birlikte dikkate alındığg sonlu eleman modeli dikkate alınmaktadır. Sonlu eleman modelinde sonsuz zemin ortamının idealleştirilebilmesi için Lysmer vd. [2] tarafından geliştirilen viskoz sınırlar ve Waas [25] tarafından geliştirilen geçirgen sınırlar kullanılmıştır.

Viskoz sınırların kullanımındaki esas amaç, yapı çevresine yayılan enerjiyi sönümleme kabiliyeti yüksek sönümleyiciler yardımıyla yarı sonsuz zemin ortamını sınırlı bir ortamla temsil etmektir. Bunun için düşey doğrultuda $\delta_{y}(t)$ yüzey yer değiştirmesi (veya $\sigma(t)$ düşey normal gerilmesi) verilen yarı sonsuz ortam (Şekil 1), sınırların yüzey normali doğrultusunda sönüm katsayısı $C_{n}$,

$C_{n}=A \rho V_{p}$ 
dikkate alınarak viskoz elemanlar ile idealleştirilmektedir (Şekil 1). Burada A, $\rho$ ve $V_{p}$ sırasıyla, sönümleyicinin tanımlandığı düğüm noktasının şekil düzlemine dik yüzey alanı, birim hacim kütlesi ve P dalgası hızıdır.

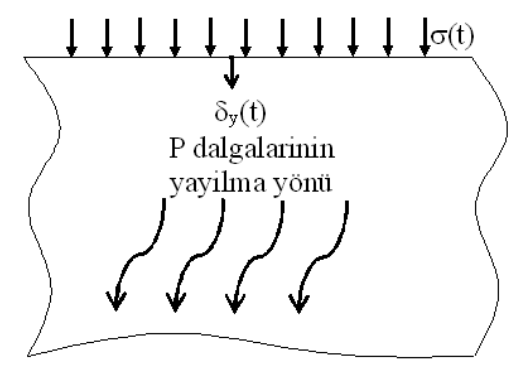

a) Yari sonsuz ortamda $P$ dalgalarinin yayilma yönï

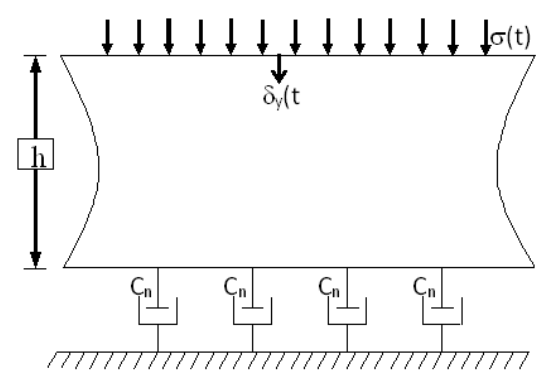

b) Yari sonsuz ortamin viskoz sönümleyici elemanlarla ideallestirilmesi

Şekil 1. P dalgalarına maruz yarı sonsuz ortam ve viskoz sönümleyici elemanlarla idealleştirilmesi

Benzer şekilde yatay doğrultuda yüzeyde $\delta_{\mathrm{x}}(\mathrm{t})$ yer değiştirmesi veya $\tau(\mathrm{t})$ kayma gerilmesi bulunan yarı sonsuz ortam (Şekil 2), sınırların teğeti doğrultusunda sönüm katsayısı $C_{t}$,

$C_{t}=A \rho V_{s}$

dikkate alınarak sonsuz ortam sınırlı olarak modellenmektedir. (Şekil 2b). Burada $\mathrm{V}_{\mathrm{s}}$, $\mathrm{S}$ dalgası hızıdır.

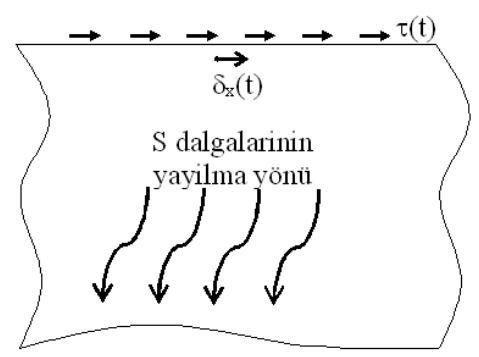

a) Yari sonsuz ortamda $S$ dalgalarinin yayilma yönü

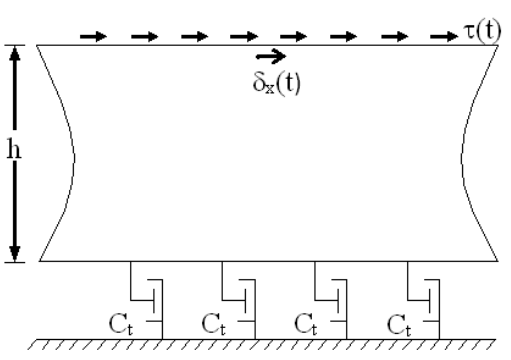

b) Yari sonsuz ortamin viskoz sönümleyici elemanlarla ideallestirilmesi

Şekil 2. S dalgalarına maruz yarı sonsuz ortam ve viskoz sönümleyici elemanlarla idealleştirilmesi

Viskoz sınırlar yardımıyla sonsuz zemin ortamında ilerleyen yansıma dalgalarının yapıya ulaşmasını engelleyerek sönümlenerek yapı-zemin etkileşim modelinin gerçeğe yakın yapısal davranışını ortaya koyabilmektedir (Şekil 3). 


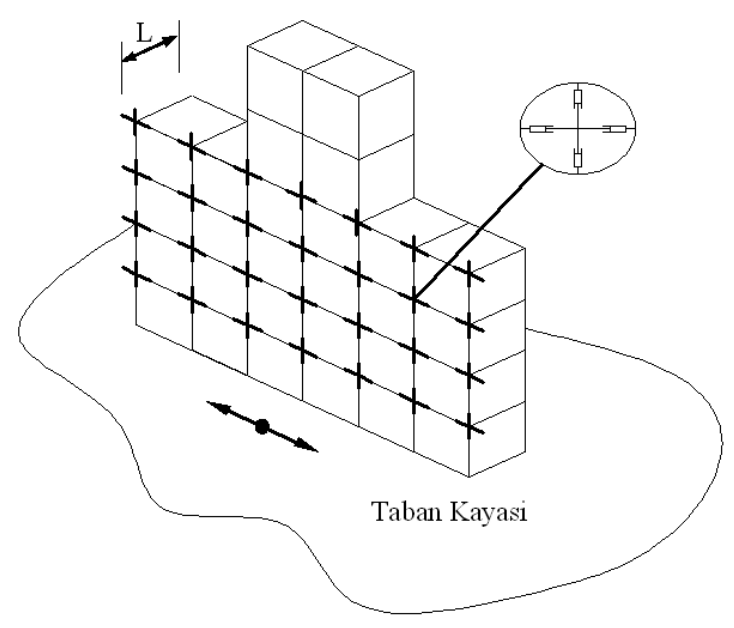

Şekil 3. Viskoz sınırlar ile oluşturulan sonlu eleman modeli

Tabakalı olarak kabul edilen sonsuz zemin ortamının yapı üzerine olan dinamik etkilerini yansıtmak üzere ilgili hareket denklemlerini içerisinde barındıran geçirgen sınırlar 1972 yılında Waas [25] tarafından geliştirilip Lysmer vd. [23] tarafından 1975 yılında sismik problemlere uygulanarak yaygın olarak kullanılmıştır. Şekil 4'te verilen tabakalı ortama göre yerdeğiştirme ve rijitlik matrislerinin oluşturulma aşamaları Sesli tarafından 2013 yılında yapılan çalışmada [26] ayrıntılı olarak verilmektedir.
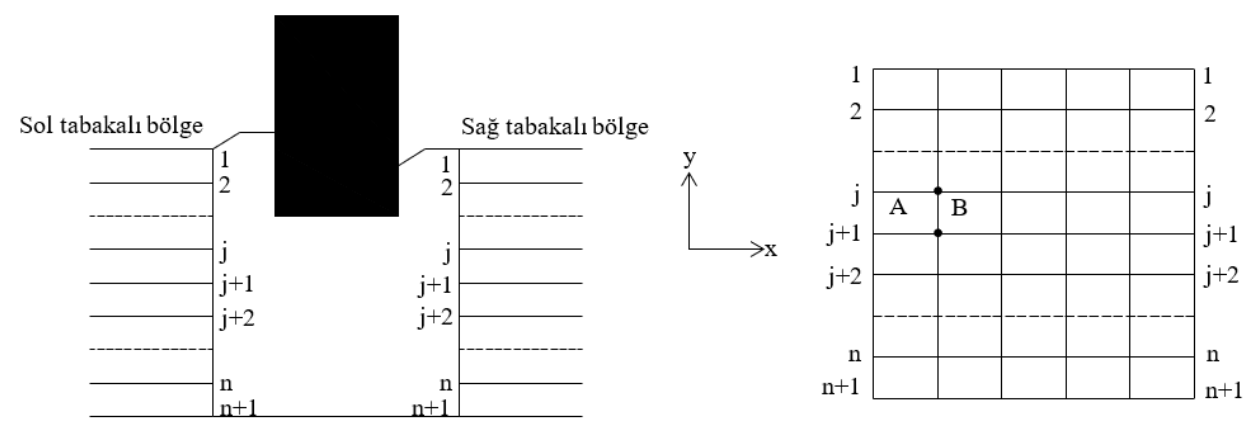

Şekil 4. Yapı-zemin sisteminin kesiti ve tabakalı zemin ortamı

\subsection{Saylsal Model}

Bu çalışmanın amacı, sonsuz zemin ortamını farklı sınır şartları yardımı ile idealleştirerek idealleştirilmiş zemin ortamının barajların dinamik davranışına olan etkisini incelemektir. Bu amaçla geleneksel olarak kullanılan rijit veya ankastre sınır modeller referans çalışması olarak dikkate alınarak sonsuz zemin ortamının viskoz ve geçirgen sınırlar ile idealleştirilmesinin etkisi ortaya konmaktadır. Baraj modeli olarak, Ankara'nın Nallıhan ilçesinde inşa edilen Sarıyar Barajı seçilmiştir. Şekil 5’te olduğu gibi 1951-1956 yılları arasında inşa edilen Türkiye'nin ilk büyük enerji barajıdır. Beton ağırlık olarak inşa edilen barajın talvegten itibaren gövde yüksekliği $90 \mathrm{~m}$, rezervuar derinliği $85 \mathrm{~m}$ ve zemine gömülen baraj gövdesi $18 \mathrm{~m}$ 'dir. 

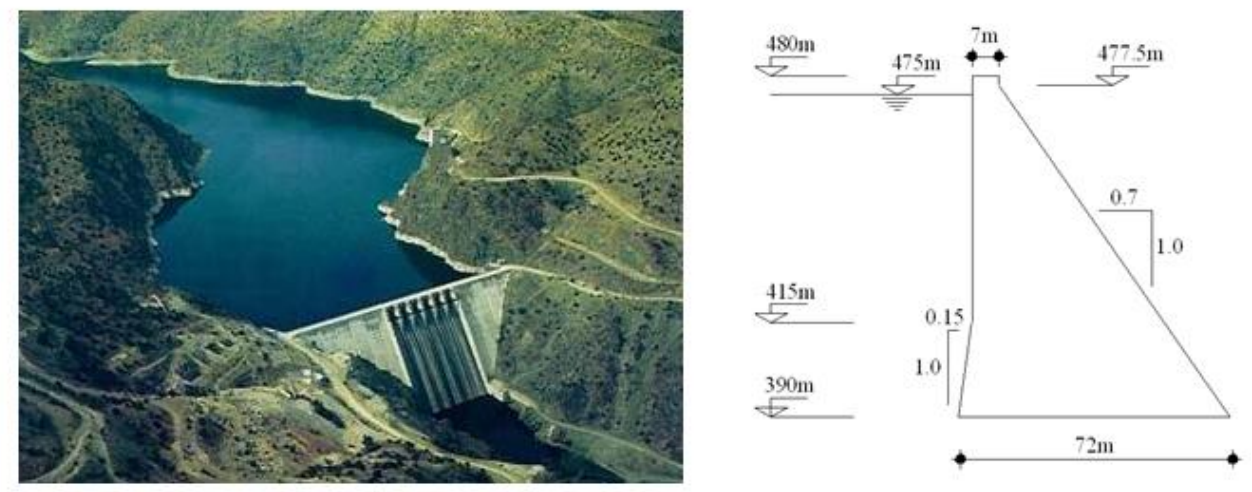

Şekil 5. Baraj ve enkesiti

Yapılan dinamik analizler için rezervuarın baraj gövdesi üzerindeki hidrodinamik basıncın hesabında Westergaard yaklaşımı kullanılmıştır. 1933 yılında Westergaard [27] tarafından önerilen bu yaklaşımda, baraj gövdesi sonsuz uzunlukta ve rijit kabul edilirken suyun sıkışmaz olduğu ve dalga oluşmadığı kabul edilmektedir. Memba yüzeyinde oluşan hidrodinamik basınç, baraj gövdesi ile birlikte titreşen bir kütle dağılımı olarak hesap edilmektedir. Kütle dağılımından baraj memba yüzeyindeki düğüm noktalarına etki edecek tekil kütleler hesaplanıp ilgili düğüm noktalarının kütlelerine eklenmektedir (Şekil 6).

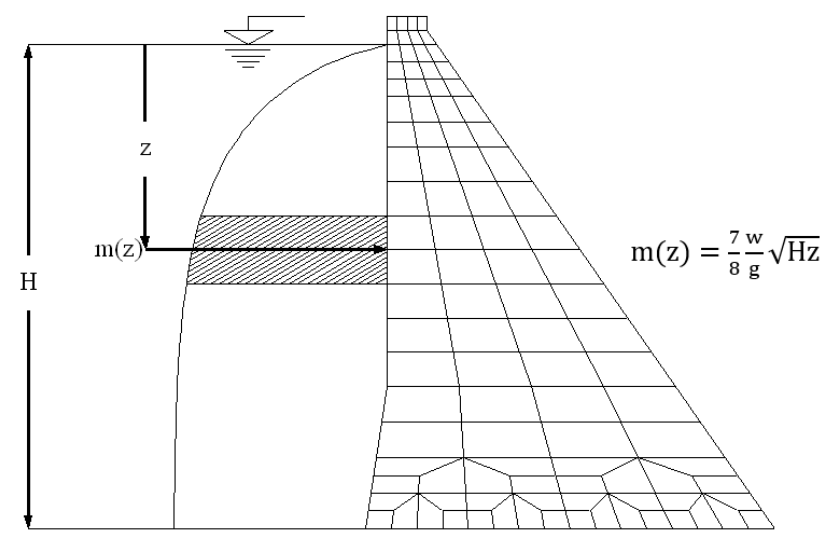

Şekil 6. Hidrodinamik kütle hesabı

Baraj-zemin etkileşim analizlerinde rezervuarın dolu olduğu kabul edilmiştir. Ağırlık barajlarının sağlam kaya üzerine inşa edilmesi nedeniyle zemin ortamında belirli bir derinlikten sonrası rijit bir tabaka olarak kabul edilmiştir. ANSYS sonlu eleman yazılımı yardımıyla yapılan analizler için tek bir zemin cinsi seçilirken FLUSH programı yardımıyla yapılan analizlerde 4 farklı zemin tabakası seçilmiştir. ANSYS sonlu eleman yazılımında oluşturulan sayısal modellerde dikkate alınan malzeme özellikleri Tablo 1'de verilmektedir. FLUSH programı yardımıyla yapılan analizlerde dikkate alınan zemin tabakalarının özellikleri Şekil 7'de verilmektedir.

Tablo 1. ANSYS' te yapılan analizlerde dikkate alınan malzeme özellikleri

\begin{tabular}{|c|c|}
\hline Baraj Gövdesi & Zemin Ortamı \\
\hline $\mathrm{E}_{\mathrm{c}}=35 \times 109 \mathrm{~N} / \mathrm{m}^{2}$ & $\mathrm{E}_{\mathrm{s}}=30 \times 109 \mathrm{~N} / \mathrm{m}^{2}$ \\
\hline$v_{\mathrm{c}}=0.15$ & $v_{\mathrm{s}}=0.20$ \\
\hline$\gamma_{\mathrm{c}}=24000 \mathrm{~N} / \mathrm{m}^{3}$ & $\gamma_{\mathrm{s}}=26000 \mathrm{~N} / \mathrm{m}^{3}$ \\
\hline
\end{tabular}




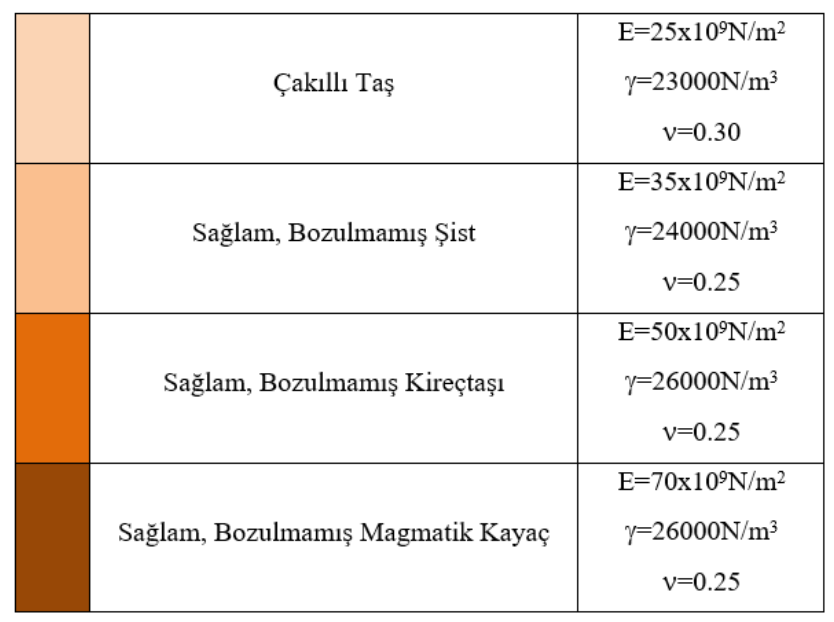

Şekil 7. FLUSH programında dikkate alınan zemin tabakalarının özellikleri

Barajların genellikle sağlam kayaların üzerine inşa edilmesi nedeniyle baraj altındaki zemin derinliği baraj yüksekliği kadar dikkate alınmıştır.

FLUSH programında oluşturulan sonlu eleman modellerinde geçirgen sınırlar, barajın yan yüzeylerinden $18 \mathrm{~m}$ uzaklığa yerleştirilmiştir (Şekil 8). Geçirgen sınırların etkinliğinin ortaya konabilmesi için zeminin geleneksel sınırlar ile sınırlandırıldığı 5 ayrı model kullanılmıştır. Baraj yan sınırından itibaren baraj yüksekliğinin (H) 1-5 katı uzaklıklarında $1 \mathrm{H}$ artımlar ile zemin hacmi oluşturulmuştur.

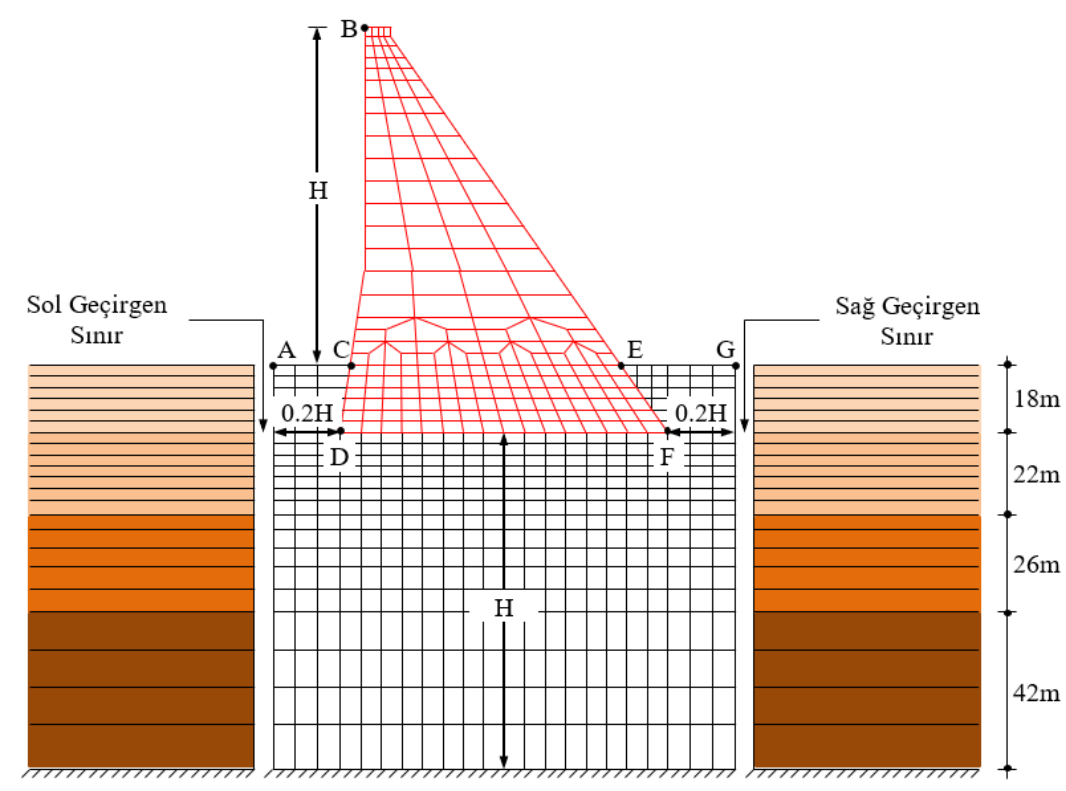

Şekil 8. FLUSH programında geçirgen sınırlı model

ANSYS sonlu eleman programında geleneksel sınırlar için yapı yan sınırından itibaren baraj yüksekliğinin 1-5 katı uzaklıklarında $0.5 \mathrm{H}$ artımlarla farklı zemin boyutlarına sahip 9 sonlu eleman modeli oluşturulmuştur. Bu 
çalışmada dikkate alınan diğer sınır şartı olan viskoz sınırlar için farklı bir analitik model oluşturulmamıştır (Şekil 9-Şekil 17).

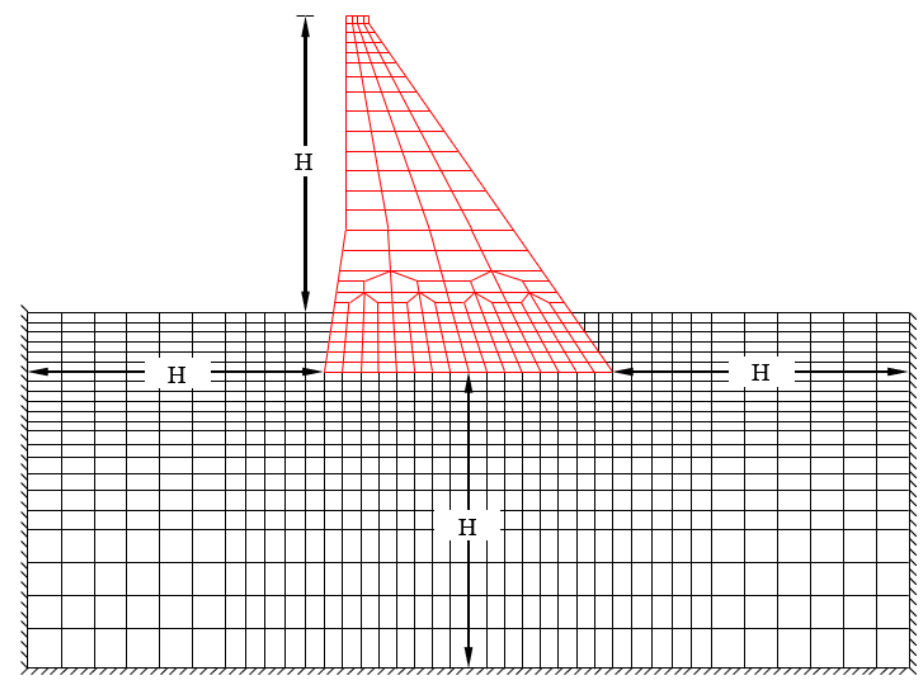

Şekil 9. Baraj yan sınırından H kadar uzaklıkta sınırlandırılmış zemin modeli

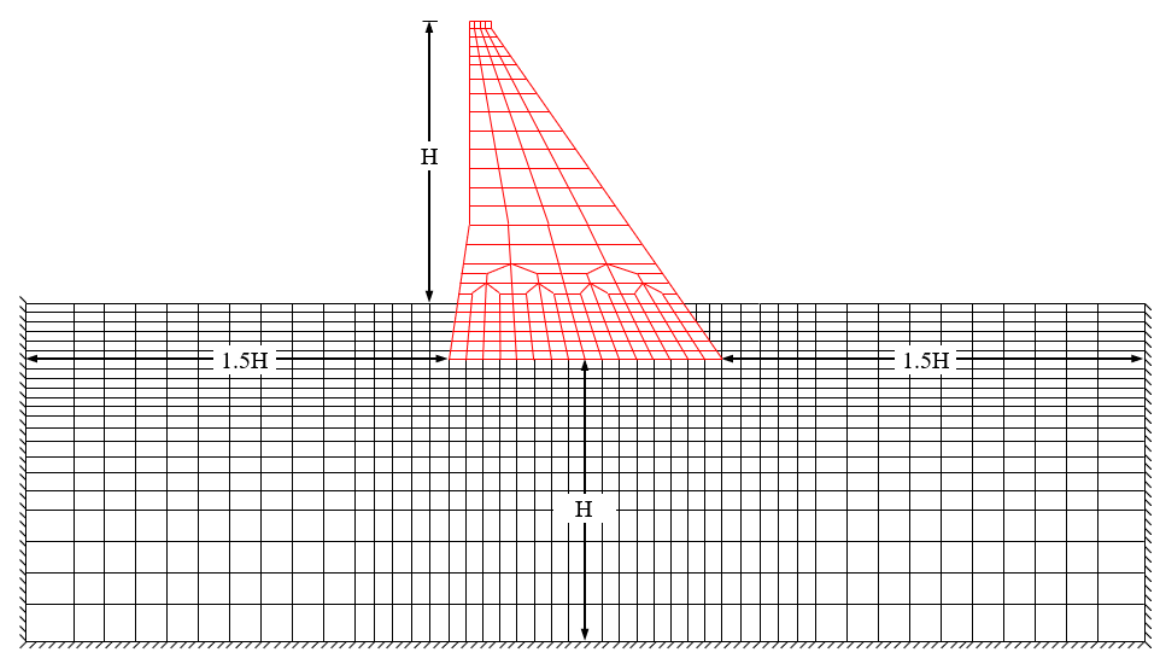

Şekil 10. Baraj yan sınırından $1.5 \mathrm{H}$ kadar uzaklıkta sınırlandırılmış zemin modeli 


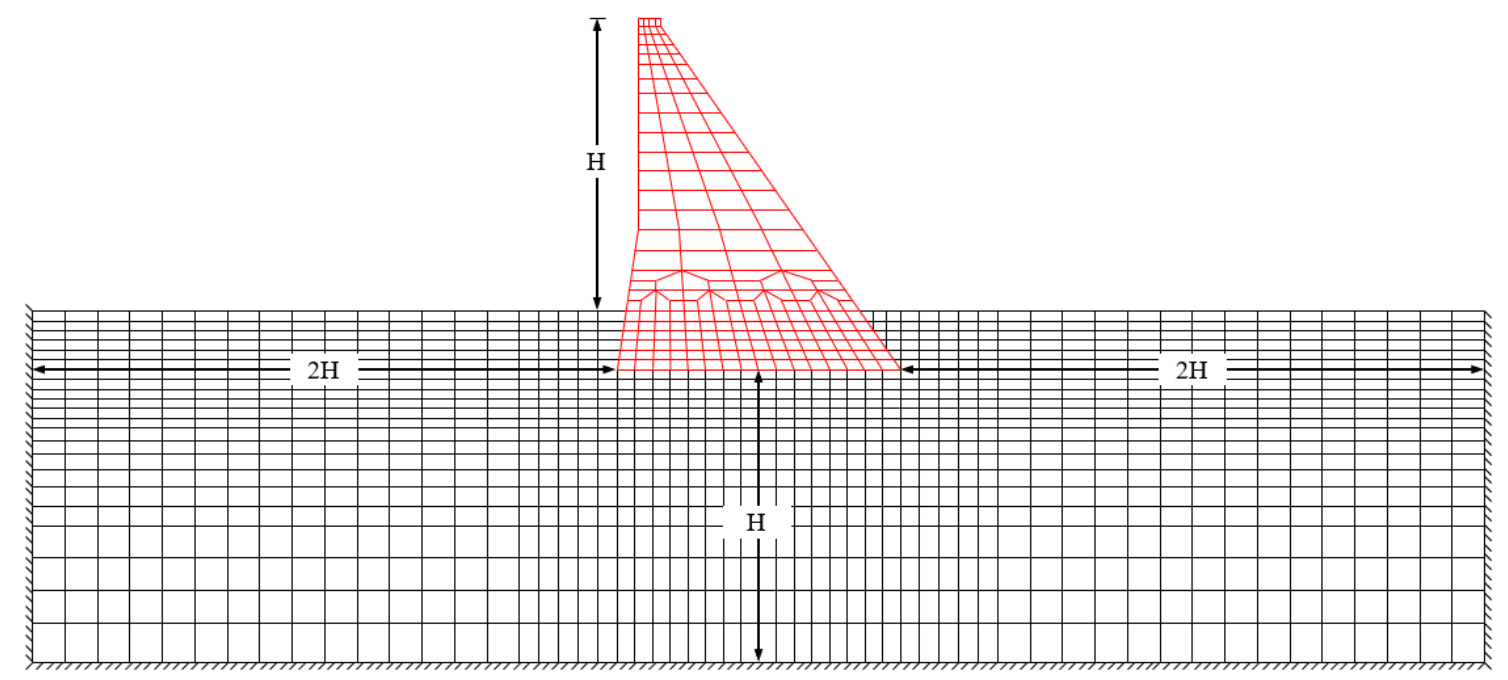

Şekil 11. Baraj yan sınırından $2 \mathrm{H}$ kadar uzaklıkta sınırlandırılmış zemin modeli

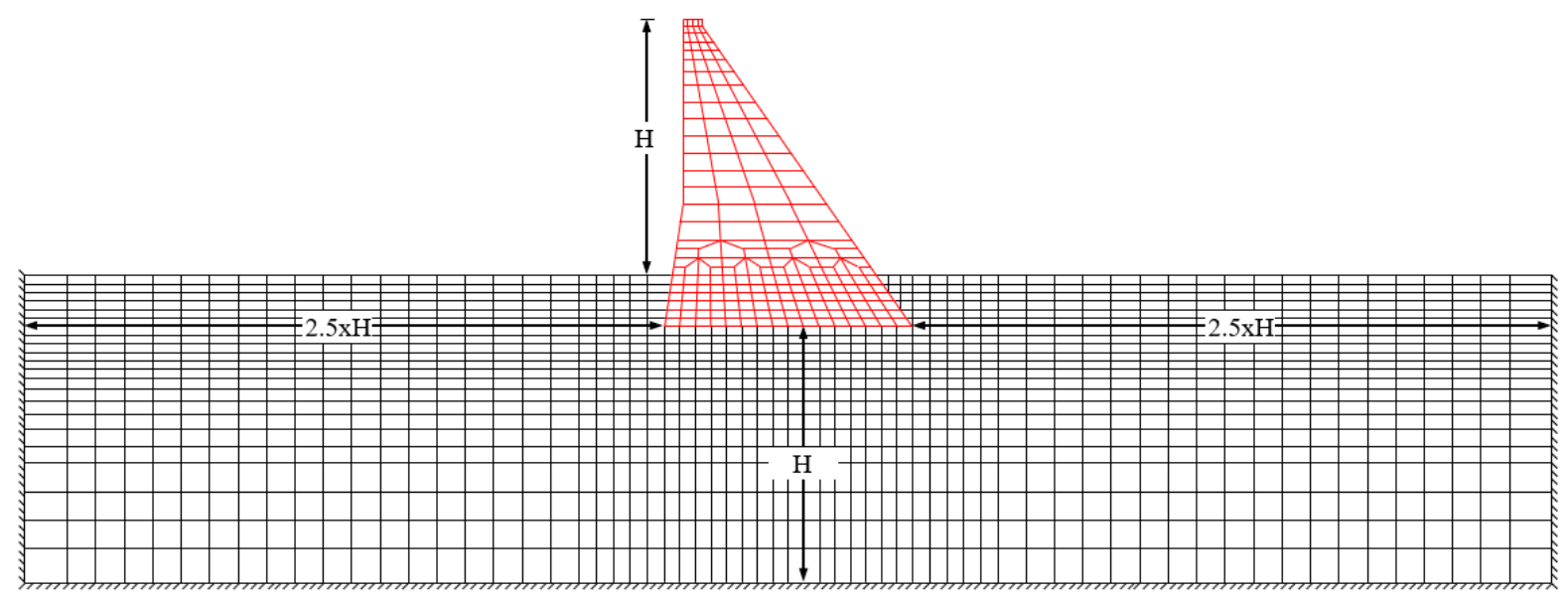

Şekil 12. Baraj yan sınırından $2.5 \mathrm{H}$ kadar uzaklıkta sınırlandırılmış zemin modeli

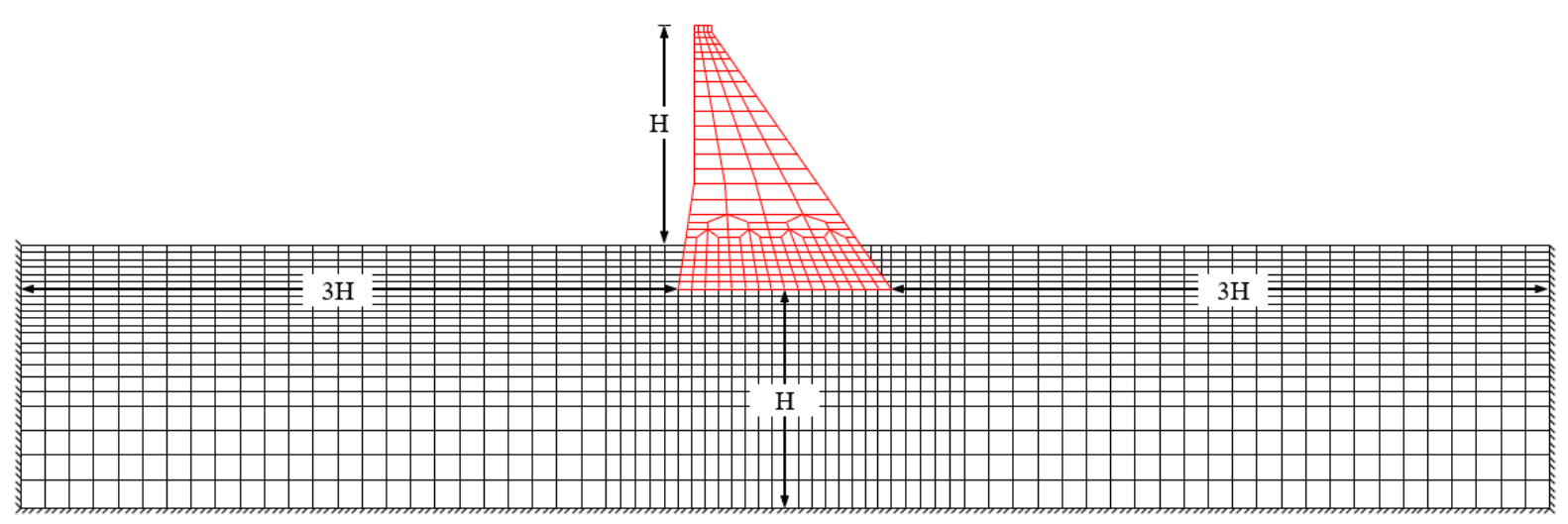

Şekil 13. Baraj yan sınırından $3 \mathrm{H}$ kadar uzaklıkta sınırlandırılmış zemin modeli 


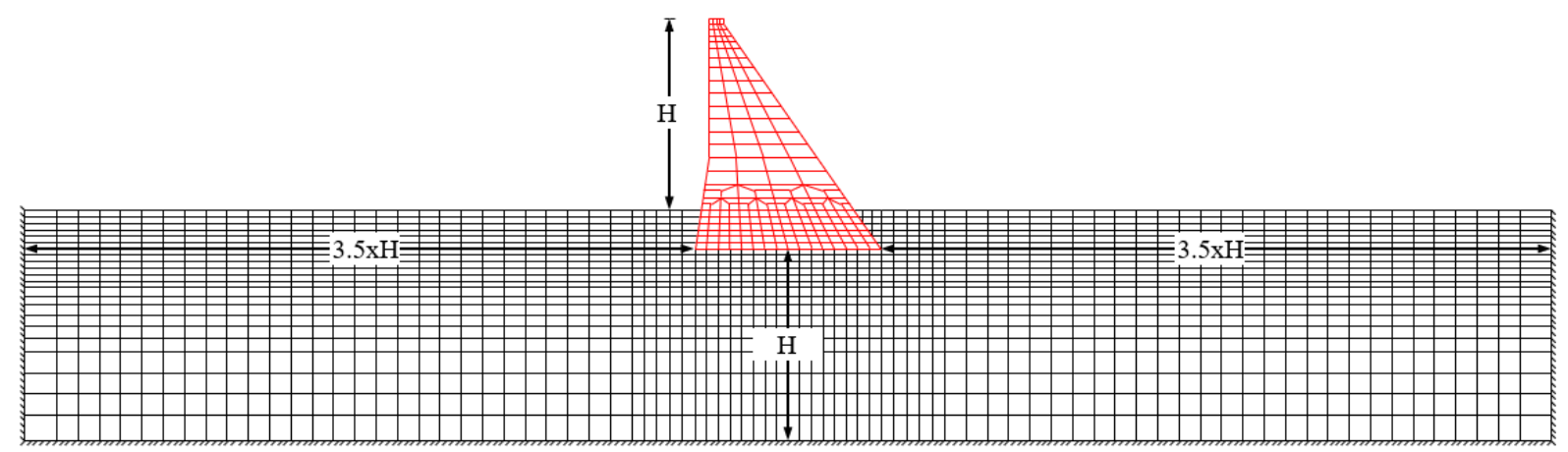

Şekil 14. Baraj yan sınırından $3.5 \mathrm{H}$ kadar uzaklıkta sınırlandırılımıs zemin modeli

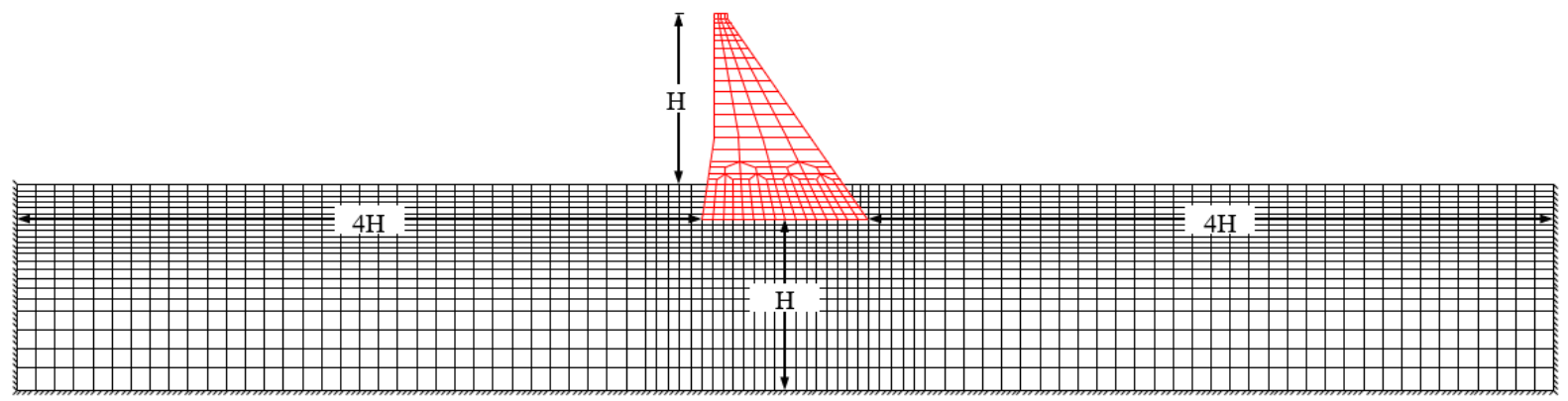

Şekil 15. Baraj yan sınırından 4H kadar uzaklıkta sınırlandırılmış zemin modeli

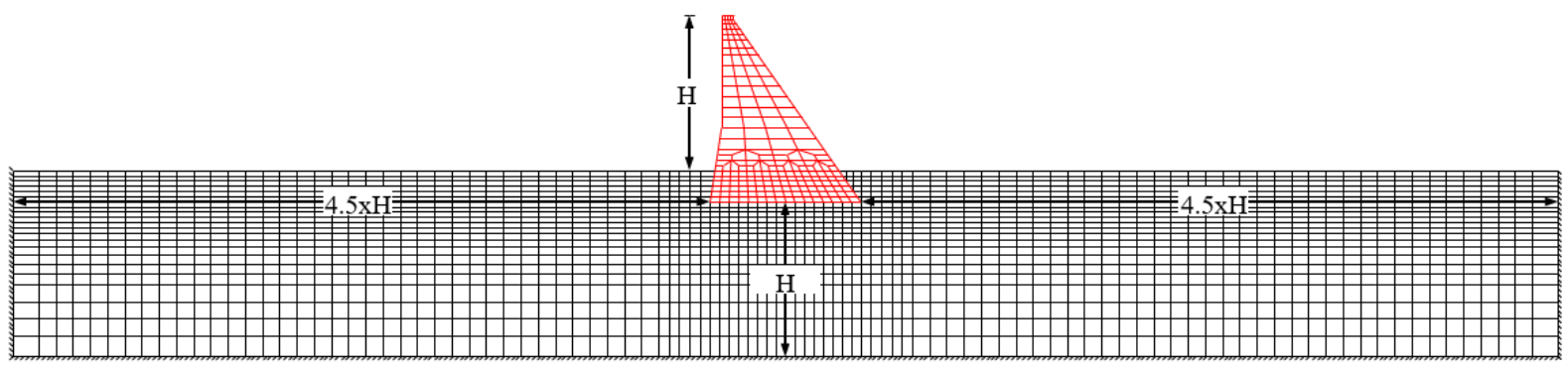

Şekil 16. Baraj yan sınırından 4.5H kadar uzaklıkta sınırlandırılmış zemin modeli

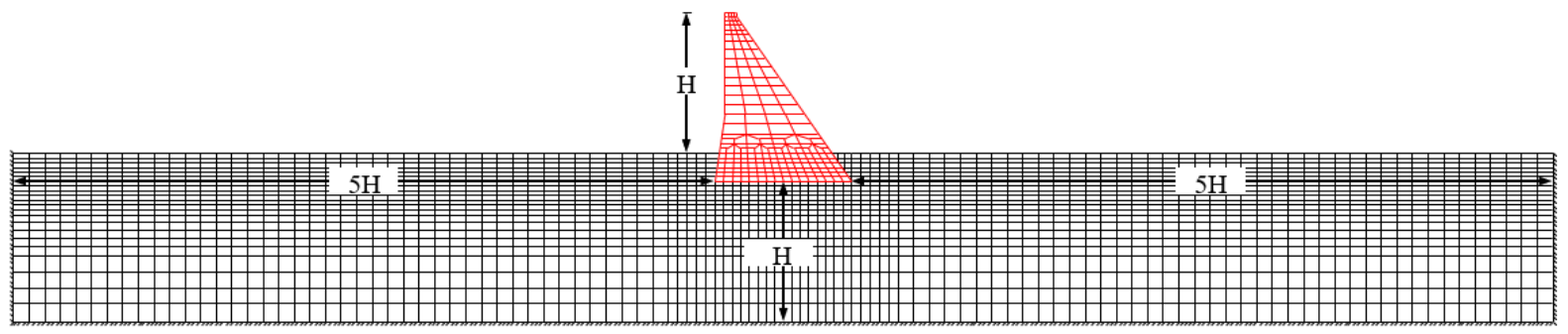

Şekil 17. Baraj yan sınırından 5H kadar uzaklıkta sınırlandırılmış zemin modeli

\subsection{Deprem Yer Hareketi I}

Geleneksel, zemin ortamında kullanılan viskoz ve geçirgen sınırların barajın dinamik davranışı üzerindeki etkisinin araştırılması üzerine yapılan bu çalışmada 13 Mart 1992 yılında meydana gelen Erzincan depremine ait Erzincan istasyon kaydının doğu-batı bileşeni [28] deprem yer hareketi olarak kullanılmıştır. Erzincan depreminin 
doğu-batı bileşenine ait ivme kaydı Şekil 18'de verilmektedir. Bu deprem kaydı serbest zemin yüzeyinden elde edilmesi nedeniyle yapı-zemin modelinin tabanına doğrudan uygulanması uygun değildir. Bu nedenle, lineer viskoelastik tabakalarda dalga yayılımını dikkate alan bir boyutlu dalga yayılımı teorisi ile serbest zemin yüzeyinde elde edilen deprem ivme kaydı baraj taban kayasına indirgenmiştir. FLUSH programı yardımıyla elde edilen indirgenmiş ivme kayıtları dinamik analizlerde baraj-zemin etkileşim modellerinde tabana uygulanmıştır. İndirgenmiş deprem ivme kaydı Şekil 19'da verilmektedir.

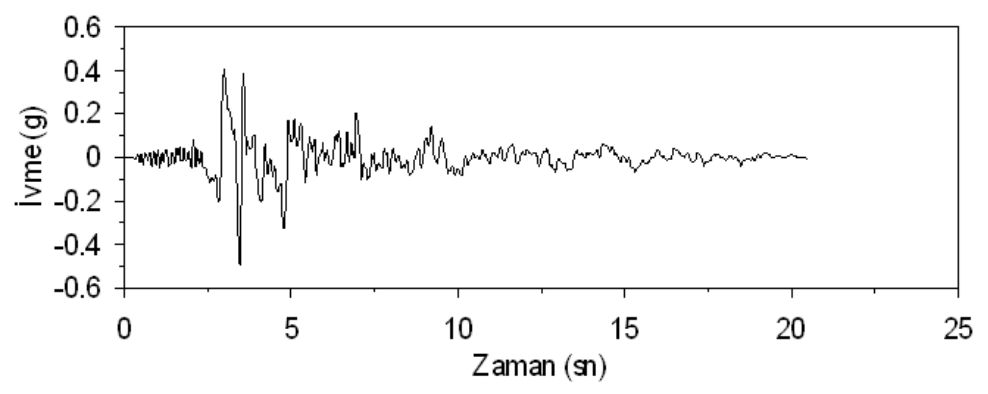

Şekil 18. 1992 Erzincan Depremi ivme kaydı

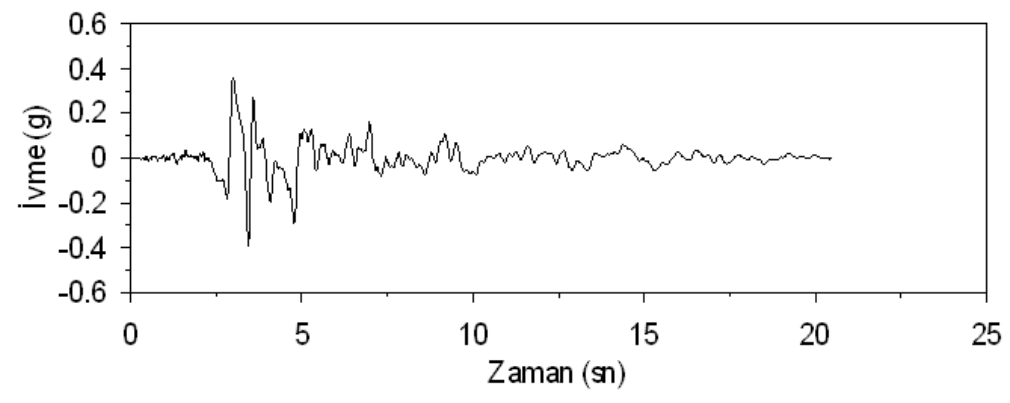

Şekil 19. 1992 Erzincan Depremi indirgenmiş ivme kaydı

\section{BULGULAR VE TARTIŞMA}

$\mathrm{Bu}$ çalışmada, baraj-zemin etkileşim modelinin zemin sınırlarında kullanılan geleneksel, viskoz ve geçirgen sınırların uygulama olarak seçilen Sarıyar beton ağılık barajının dinamik davranışı üzerindeki etkisi incelenmektedir. İlk analizler ANSYS programı yardımıyla geleneksel sınırlar ile sınırlandırılmış zemin hacimlerine sahip baraj-zemin etkileşim modeli üzerinde gerçekleştirilmiştir. Erzincan depremi etkisinde baraj memba yüzeyinde baraj yüksekliği boyunca meydana gelen en büyük yerdeğiştirmeler incelenmiştir. Kret noktasının maksimum yer değiştirme değerleri sırasıyla, 9.43, 10.74, 11.55, 12.50, 13.28, 13.82, 14.30, 14.60, $14.88,14.99,15.06 \mathrm{~cm}$ olarak elde edilmektedir. Geleneksel sınırların barajdan yatayda en az baraj yüksekliğinin 5 katı uzaklıkta olması durumunda zemin sınırlarının etkisi kaybolmaktadır (Şekil 20). 


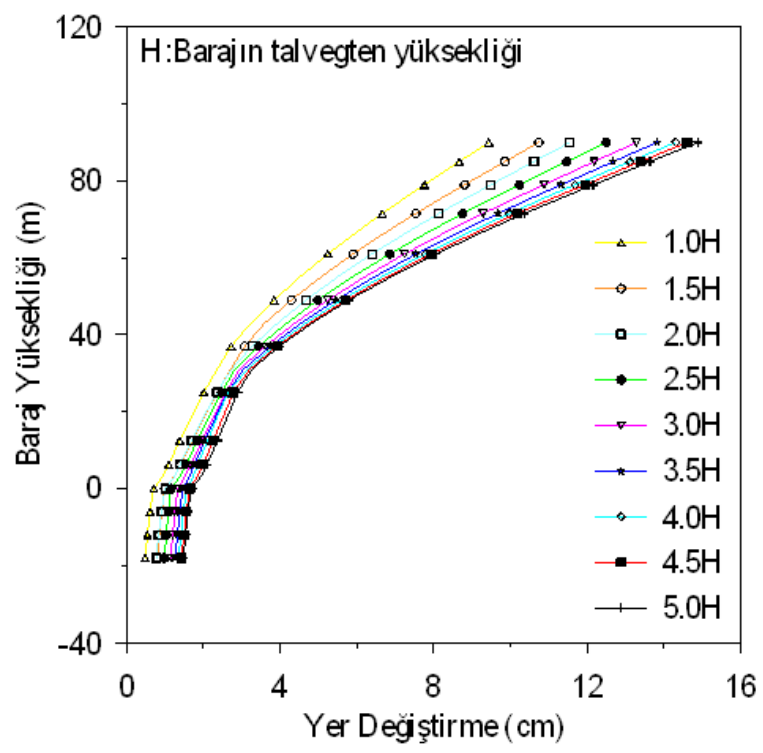

Şekil 20. Geleneksel sınırlı modellere göre baraj memba yüzeyinde yüksekliğe bağlı yerdeğiştirme değişimi

ANSYS sonlu eleman programında gerçekleştirilen analizler sonucunda memba yüzeyindeki sonlu elemanlarda elde edilen normal gerilmelerin baraj yüksekliği boyunca değişimi değerlendirilmiştir. Baraj yüksekliği boyunca memba yüzeyindeki x ve y yönündeki normal gerilme değişimi Şekil 21 ve Şekil 22'de verilmektedir. Zemin yüzeyine yakın noktalarda en büyük değerine ulaşan yatay doğrultulu normal gerilmeler her bir model için surasiyla, 6090.15, 6543.05, 7230.21, 7787.57, 8404.32, 8940.48, 9357.11, 9674.91, $9871.55 \mathrm{kN} / \mathrm{m}^{2}$ olmaktadır. Düşey doğrultulu normal gerilmeler ise sırasıyla, 15930.40, 18020.30, 19392.10, 21169.80, 22816.10, 24156.80, $25152.50,25916.80,26337.50 \mathrm{kN} / \mathrm{m}^{2}$ olmaktadır. Buna göre, zemin sınırlarının geleneksel sınırlar ile barajdan $5 \mathrm{H}$ mesafesinde sınırlandırılması durumunda gerilmeler arasındaki sıçramaların azaldığı ve zemin sınırlarının etkisinin bu mesafeden sonra kaybolduğu görülmektedir.

ANSYS programı yardımıyla viskoz sınırlar ile sınırlandırılmış zemin hacimlerine sahip baraj-zemin etkileşim modeli üzerinde dinamik analizler gerçekleştirilmiştir. Burada viskoz sınırlar sadece baraj gövdesinden $3 \mathrm{H}$ uzaklıkta zemin hacmine kadar uygulanmıştır. Bunun üzerindeki modellerde kullanılmasına gerek duyulmamıştır. Viskoz sınırlı modellerde, kret noktasının maksimum yer değiştirme değerleri sırasıyla 5.80, 6.28, 6.69, 7.01, 7.06 $\mathrm{cm}$ olmaktadır. Buna göre, viskoz sınırların etkisi ile baraj gövdesinin $3 \mathrm{H}$ ötesinde yerdeğiştirmelerdeki sıçramalar sıfira yaklaşmakta ve zemin ortam sonsuz gibi davranış sergilemektedir (Şekil 23).

Viskoz sınırların kullanıldığı modeller için baraj yüksekliği boyunca memba yüzeyindeki x ve y yönündeki normal gerilme değişimi Şekil 24ve Şekil 25'te verilmektedir. Zemin yüzeyine yakın noktalarda en büyük değerine ulaşan yatay doğrultulu normal gerilmeler her bir model için sırasıyla, 3509.47, 3675.49, 3893.53, 4131.79, 4167.78 $\mathrm{kN} / \mathrm{m}^{2}$ elde edilmiştir. Düşey doğrultulu normal gerilmeler ise sırasıyla, 8436.37, 9070.74, 9663.21, 10052.6, $9983.31 \mathrm{kN} / \mathrm{m}^{2}$ elde edilmiştir. Buna göre, zemin sınırlarının geleneksel sınırlar ile barajdan $3 \mathrm{H}$ mesafesinde sınırlandırılması durumunda gerilmeler arasındaki sıçramalar azalarak sınır etkisi kaybolmaktadır. 


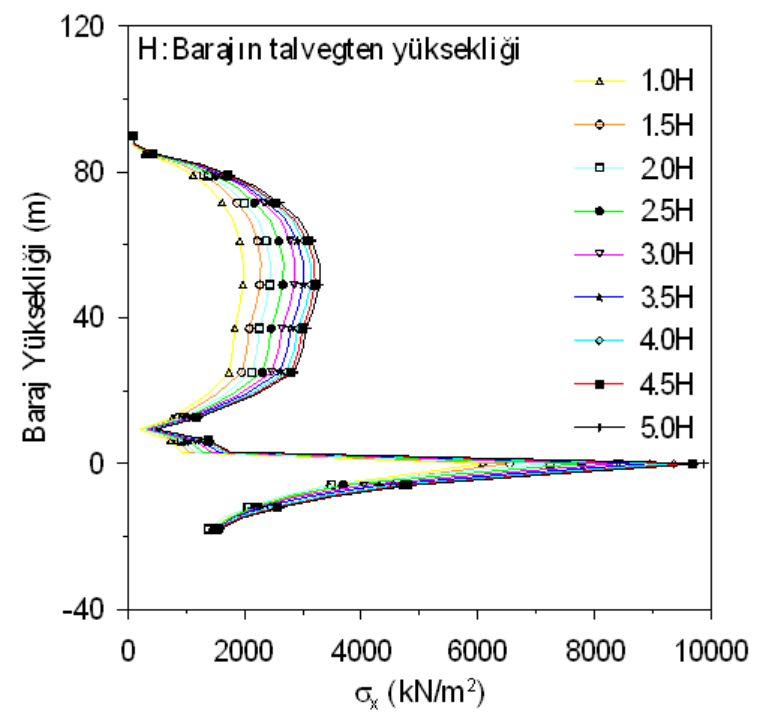

Şekil 21. Geleneksel sınırlı modellere göre baraj memba yüzeyinde yüksekliğe bağlı yatay doğrultulu normal gerilme değişimi

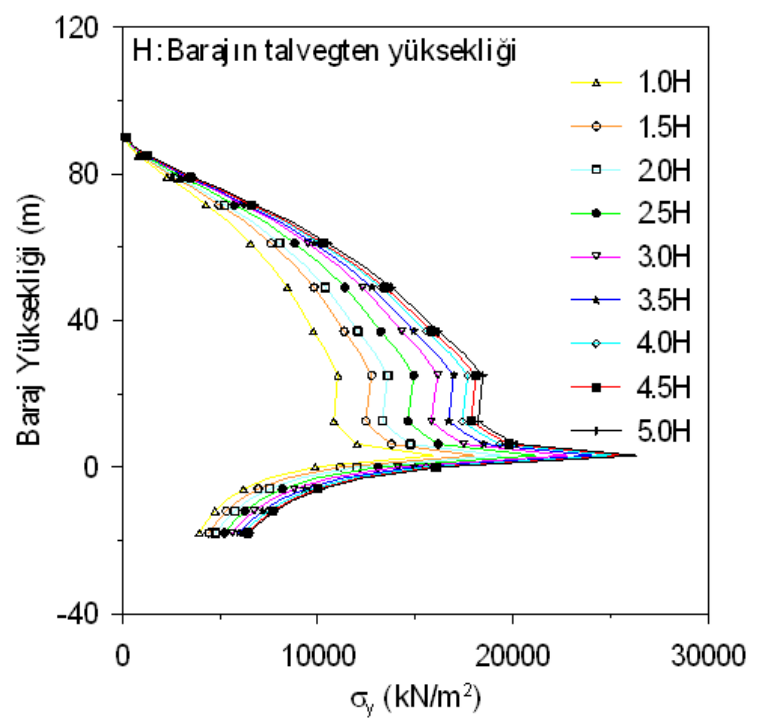

Şekil 22. Geleneksel sınırlı modellere göre baraj memba yüzeyinde yüksekliğe bağlı düşey doğrultulu normal gerilme değişimi 


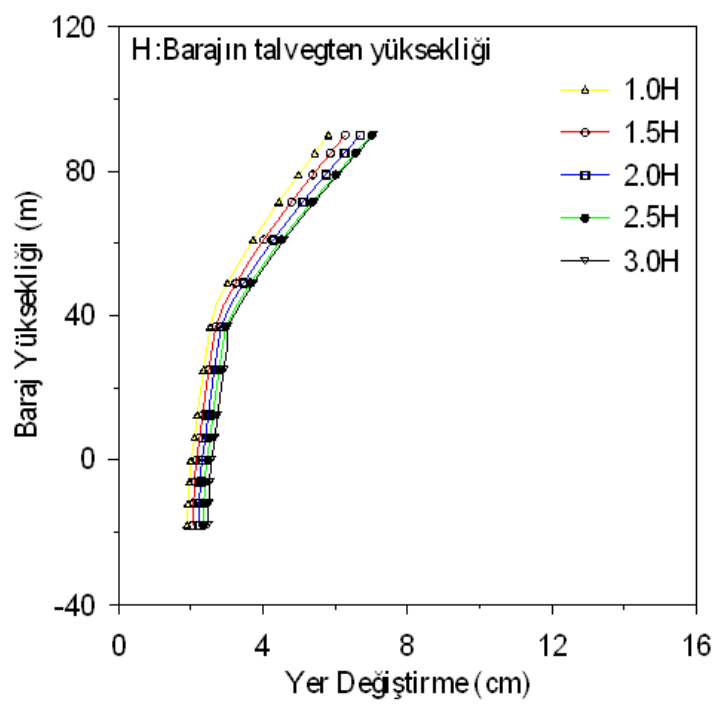

Şekil 23. Viskoz sınırlı modellere göre baraj memba yüzeyinde yüksekliğe bağlı yerdeğişstirme değişimi

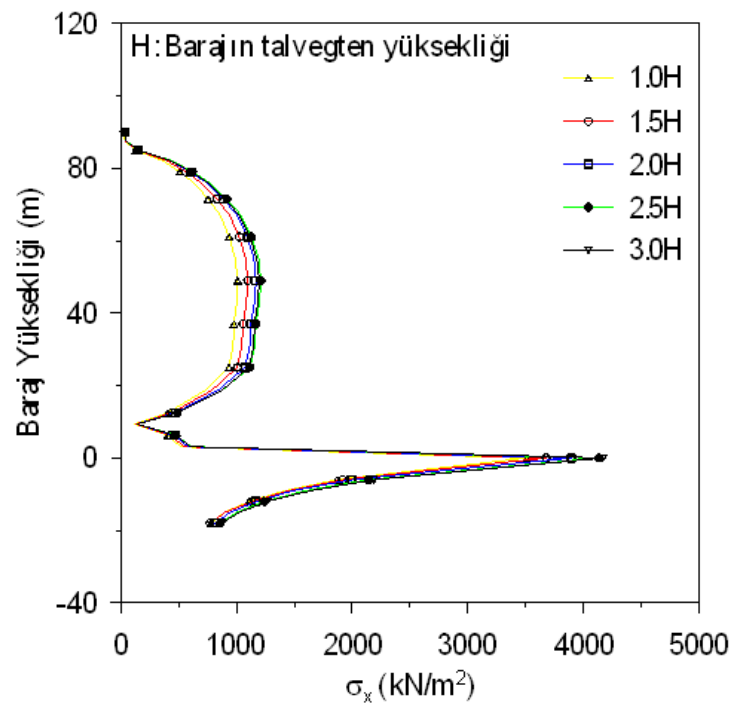

Şekil 24. Viskoz sınırlı modellere göre baraj memba yüzeyinde yüksekliğe bağlı yatay doğrultulu normal gerilme değişimi

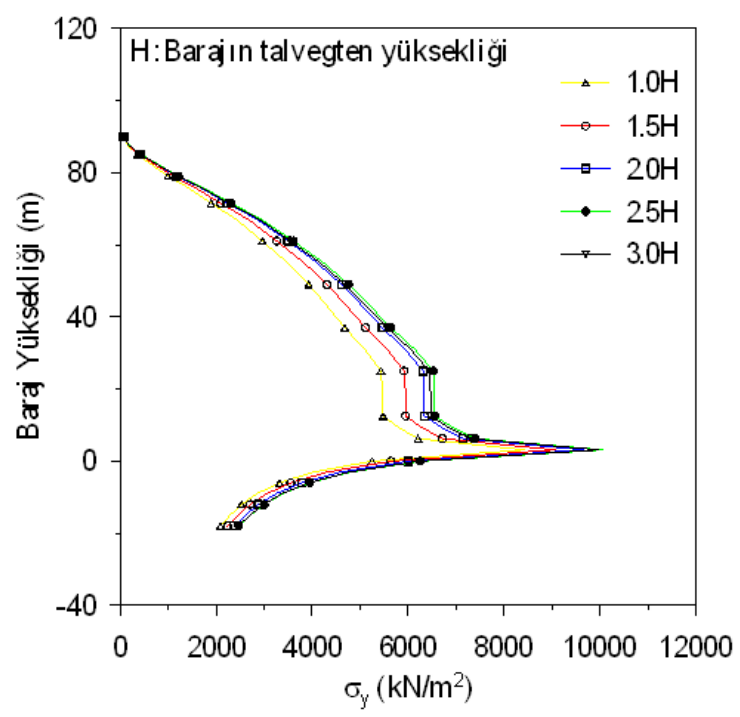

Şekil 25. Viskoz sınırlı modellere göre baraj memba yüzeyinde yüksekliğe bağlı yatay doğrultulu normal gerilme değişimi 
Geçirgen sınırların etkinliğinin ortaya konabilmesi için geçirgen sınırlar baraj gövdesinden $0.2 \mathrm{H}$ uzaklıkta teşkil edilirken, referans çalışması olarak baraj gövdesinden $1 \mathrm{H}, 2 \mathrm{H}, 3 \mathrm{H}, 4 \mathrm{H}$ ve $5 \mathrm{H}$ uzaklıkta teşkil edilen geleneksel sınırlı zemin modelleri dikkate alınmıştır. Baraj kret noktasına ait spektrumlar elde edilmiştir. Baraj-zemin etkileşim modellerinin hakim mod frekans değeri yaklaşık 3-4 Hz arasında değişmektedir. Geçirgen sınırlı model ile 5H zemin hacmine sahip geleneksel sınırlı modele ait spektral değerlerin oldukça uyumlu olduğu Şekil 26Şekil 28 arasında verilen grafiklerde görülmektedir.

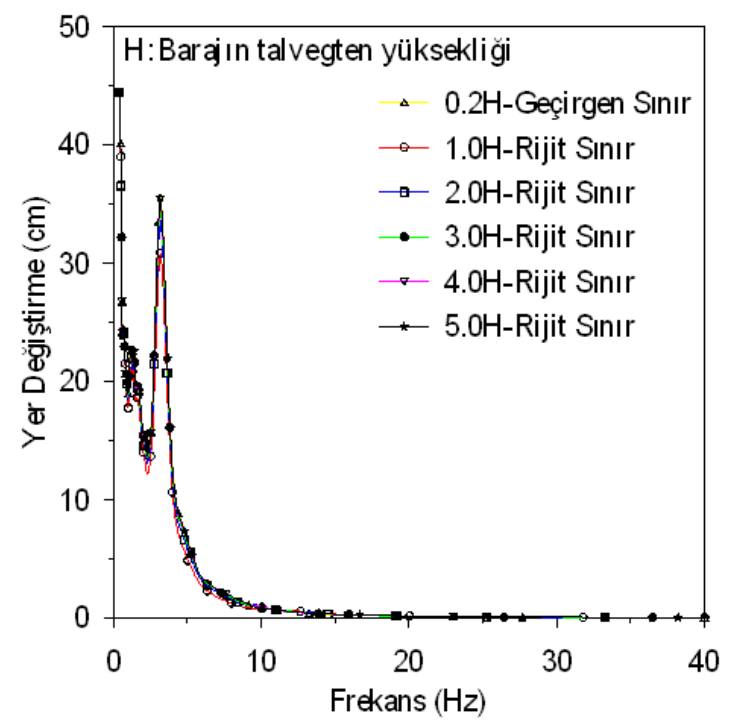

Şekil 26. Kret noktasındaki yerdeğiştirme spektrumu

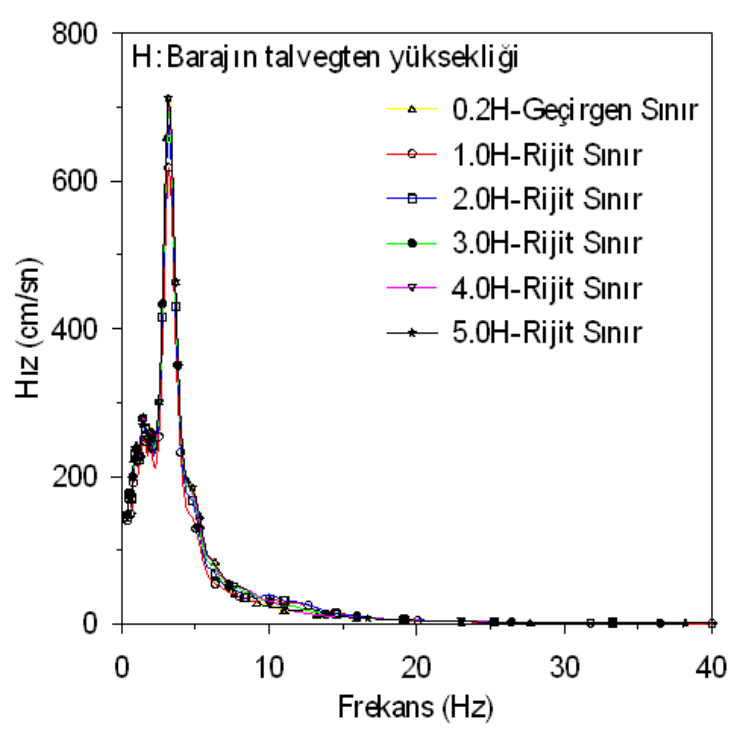

Şekil 27. Kret noktasındaki hız spektrumu 


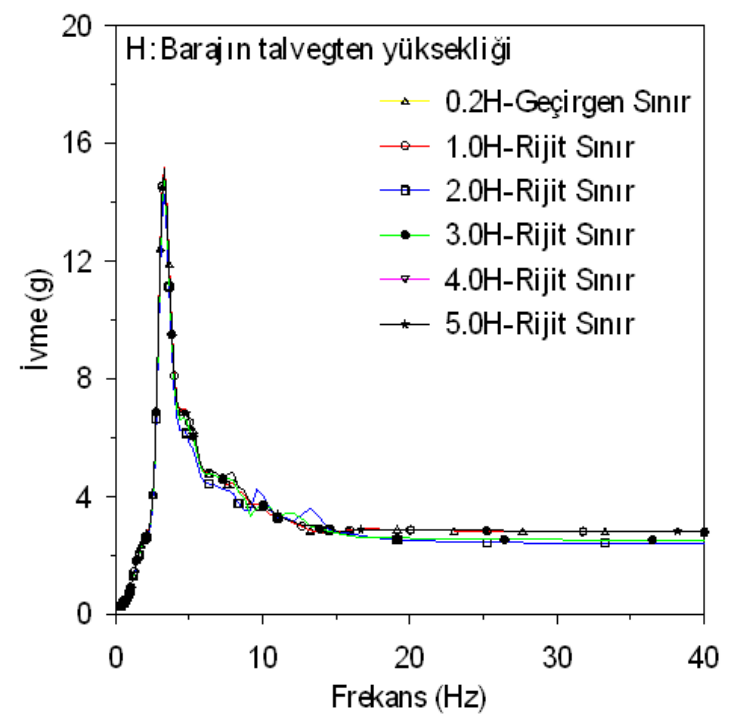

Şekil 28. Kret noktasındaki ivme spektrumu

\section{SONUÇLAR}

Baraj gibi kütlesel yapıların dinamik davranışlarının belirlenmesinde yapıyı zeminden bağımsız olarak kabul etmek uygun bir yaklaşım olmamaktadır. Dinamik titreşim altında baraj gövdesi zemin davranışını etkilerken, zemin davranışı da yapı üzerinde etkili olmaktadır. Bu etkilerden en önemlisi de baraj gövdesinden yansıyan dalgaların yayılımı olmaktadır. Sonsuz zemin ortamında yayılan bu dalgalar zemin içerisinde sönümlenmektedir. Oysaki barajların dinamik analizlerinde sonsuz zemin hacmini temsil etmek işlem maliyeti açısından pek mümkün değildir. $\mathrm{Bu}$ nedenle, sonsuz zemin ortamının sınırlı zemin ortamı ile uygun yaklaşımlar vasıtası ile idealleştirilmesi gerekmektedir. Bu çalışmada yapı-zemin etkileşiminde zeminin idealleştirilmesi için önerilen 3 farklı sınır şartı kullanılarak bu sınır şartlarının yapı davranışı üzerindeki etkisi incelenmektedir. Uygulama için Sarıyar beton ağırlık barajı seçilmiştir. Deprem yer hareketi olarak 1992 Erzincan depremi dikkate alınmıştır. Yapılan çalışmada şu sonuçlar elde edilmiştir.

- Geleneksel sınırlı modellerin direk integrasyon tekniği olan ANSYS ve kompleks davranış tekniği olan FLUSH ile yapılan dinamik yapısal çözümlemeleri sonucu zeminin sınırı yapıdan yapı yüksekliğinin en az 5 katı uzaklıklarda olması durumunda yapı davranışı değişmemektedir.

- Geleneksel sınırlar yerine viskoz sınır kullanılması durumunda zemin sınırı yapı yüksekliğinin yaklaşık 3 katı seviyesine kadar düşürülebilmektedir.

- Geçirgen sınırlar yapı yüksekliğinin 0.2 katı uzaklıkta yerleştirilmesi gerçek veya sonsuz zemin ortamının idealleştirilmesi için yeterli olmaktadır.

- Kompleks davranış tekniği ve direk integrasyon tekniği ile yapılan dinamik analizler göz önüne alındığında tam bir sonsuz zemin ortamının idealleştirilebilmesi için kullanılan viskoz ve geçirgen sınırlar, geleneksel sınırlı modellerde kullanılan sonlu eleman sayısını $\% 80$ azaltılabilmektedir.

Yapılan analizlerde tüm malzemeler lineer elastik olarak tanımlanmıştır. Tam bir zemin davranışının yapı üzerindeki etkisinin incelenmesi için elastik ötesi malzeme davranışının dikkate alınması gerekmektedir. Ayrıca, bu çalışmada yapı ve zemin arasındaki sonlu eleman düğüm noktaları sabit tutulmaktadır. Baraj gibi rijit yapılarda 
yapı-zemin arasında tam temas sağlansa bile titreşim etkisinde kayma hareketinin dikkate alınması gerekmektedir. Bu nedenle ileride yapılacak olan çalışmalarda baraj ve zemin arasındaki yüzeyde kayma etkisi dikkate alınacaktır.

\section{KAYNAKLAR}

[1] Aydınoğlu MN (1992) Development of analytical techniques in soil-structure interaction. NATO ASI Series-Developments in Dynamic Soil-Structure Interaction, 390:25-42.

[2] Lysmer J, Kuhlemeyer RL (1969) Finite dynamic model for infinite media. J. Eng. Mech. Div, 95: 859-877. https://doi.org/10.1061/JMCEA3.0001144

[3] Lysmer J (1970) Lumped mass method for Rayleigh waves. Bull. Seismol. Soc. Am. 60:89-104. https://doi.org/10.1785/BSSA0600010089

[4] Smith WD (1974) Nonreflecting plane boundary for wave propagation problems. J. Comput. Phys. 15:492503. https://doi.org/10.1016/0021-9991(74)90075-8

[5] Hwang RN, Lysmer J, Berger E (1975) Simplified three-dimensional soil-structure interaction study. Second ASCE Specialty Conference on Structural Design of Nuclear Plant Facilities 786-808.

[6] Bettes P (1977) Infinite elements. Int. J. Numer. Methods Eng. 11:53-64. https://doi.org/10.1002/nme.1620110107

[7] Clayton R, Engquist B (1977) Absorbing boundary conditions for acoustic and elastic wave equations. Bull. Seismol. Soc. Am. 67:1529-1540. https://doi.org/10.1785/BSSA0670061529

[8] Dumanoğlu AA (1980) A method for the dynamic analysis of embedded structures. The Seventh World Conference on Earthquake Engineering, İstanbul, Turkey, 335-339.

[9] Liao ZP, Wong HL (1984) A transmitting boundary for the numerical simulation of elastic wave propagation. Soil Dyn. and Earthquake Eng. 3:174-182. https://doi.org/10.1016/0261-7277(84)90033-0

[10] Berenger JP (1994) A perfectly matched layer for the absorption of electromagnetic waves. J. Comput. Phys. 114:185-200.https://doi.org/10.1006/jcph.1994.1159

[11] Chuhan Z, Xinfeng C, Guanglun W (1999) A coupling model of fe-be-ie-ibe for non-linear layered soilstructure interactions. Earthquake Eng. Struct. Dyn. 28:421-441. https://doi.org/10.1002/(SICI)10969845(199904)28:4<421::AID-EQE824>3.0.CO;2-J

[12] Wolf JP, Song C (2000). Finite-element modelling of unbounded media. John Wiley \& Sons Ltd., Chichester

[13] Park S, Antin N (2003) A discontinuous galerkin method for seismic soil-structure interaction analysis in the time domain. Earthquake Eng. Struct. Dyn. 33:285-293. https://doi.org/10.1002/eqe.353

[14] Liu J, Gu Y, Wang Y, Li B (2006). Efficient procedure for seismic analysis of soil-structure interaction system, Tsinghua Science and Technology, 11:625-631. https://doi.org/10.1016/S1007-0214(06)70244-9

[15] Du X, Zhang Y, Zhang B (2006). Nonlinear seismic response analysis of arch dam-foundation systemspart I dam-foundation rock interaction, Bull. Earthquake Eng. 5:105-119. DOI 10.1007/s10518-006-9012-3

[16] Kucukcoban S, Kallivokas LF (2011). Mixed perfectly-matched-layers for direct transient analysis in 2D elastic heterogeneous media, Comput. Methods Appl. Mech. Engrg. 200:57-76. 10.1016/J.CMA.2010.07.013

[17] Kucukcoban S, Kallivokas LF (2013). A symmetric hybrid formulation for transient wave simulations in PML-truncated heterogeneous media, Wave Motion 50:57-79. https://doi.org/10.1016/j.wavemoti.2012.06.004 
[18] Mazzotti M, Bartoli I, Marzani A, Viola E (2013). A coupled SAFE-2.5 D BEM approach for the dispersion analysis of damped leaky guided waves in embedded waveguides of arbitrary cross-section, Ultrason. 53:12271241. https://doi.org/10.1016/j.ultras.2013.03.003

[19] Mazzotti M, Bartoli I, Marzani A (2014). Ultrasonic leaky guided waves in fluid-coupled generic waveguides: hybrid finite-boundary element dispersion analysis and experimental validation, J Appl Phys. 115:143512. https://doi.org/10.1063/1.4870857

[20] Poula MK, Zervab A (2019). Comparative evaluation of foundation modeling for SSI analyses using two different ABC approaches: Applications to dams, Eng. Struct. 200:109725. https://doi.org/10.1016/j.engstruct.2019.109725

[21] Hibbit, Karlsson, Sorensen (2007) ABAQUS/Standard Analysis User's Manual, USA.

[22] Zhang W, Seylabi EE, Taciroglu E (2019) An ABAQUS toolbox for soil-structure interaction analysis, Comput. Geotech. 114:103143. https://doi.org/10.1016/j.compgeo.2019.103143

[23] Lysmer J, Udaka T, Tsai C, Seed HB (1975). FLUSH-A computer program for approximate 3-d analysis of soil-structure interaction problems, Report No. EERC 75-30, Earthquake Engineering Research Center, University of California, Berkeley, California.

[24] ANSYS (2013) Swanson analysis system, Pennsylvania, USA

[25] Waas G (1972) Linear two-dimensional analysis of soil dynamics problems in semi-infinite layered media, Dissertation, University of California

[26] Sesli H (2013) Influence of soil boundary conditions on dynamic behavior of soil-structure interaction systems. Dissertation, Karadeniz Technical University

[27] Westergaard HM (1933) Water Pressures on Dams during Earthquakes. Transactions of the American Society of Civil Engineers, 98:418-433. https://doi.org/10.1061/TACEAT.0004496

[28] PEER (Pacific Earthquake Engineering Research Centre) (2021), http://peer.berkeley.edu/smcat/data, 15 December 2021. 